\title{
Degradation and Adsorption of a Seed Fungicide Pefurazoate in Paddy Soil
}

\author{
Mitsuaki Takenaka, Shoji SakaI,* Hitoshi Nishida, \\ Shuichiro Kimura and Hiroshi Hase \\ Ube Laboratory, Agrochemical Research Department, UBE Industries, Ltd., \\ Kogushi Ube 755, Japan
}

(Received March 6, 1991)

\begin{abstract}
Fate of the fungicide, pefurazoate (pent-4-enyl $N$-furfuryl- $N$-imidazol-1-ylcarbonyl-DLhomoalaninate, Healthied( $($ ) in flooded mineral and volcanic ash soils was investigated with ${ }^{14} \mathrm{C}$-labeled pefurazoate. ${ }^{14} \mathrm{C}$-Pefurazoate, when applied at $1 \mathrm{ppm}$, was quite easily degraded with a half-life of less than one week in both soils. Pent-4-enyl $N$-furfuryl-DL-homoalaninate, $N$-furfuryl-DL-homoalaninate, 1-[(RS)-1-carboxylato-propyl]-3-hydroxypyridinium, and $N$ (furan-2-ylcarbonyl)glycine were identified as major degradation products, amounting to less than $10 \%$ of the applied radioactivity. The radioactivity in the soil decreased due to the evolution of ${ }^{14} \mathrm{CO}_{2}$, which was an ultimate metabolite of pefurazoate. The Freundlich adsorption coefficient of pefurazoate was 16.3 in the mineral soil and 21.9 in the volcanic ash soil, suggesting pefurazoate was not adsorbed tightly by the soils.
\end{abstract}

\section{INTRODUCTION}

Pefurazoate (Healthied ${ }^{\circledR}$, pent-4-enyl $N$ furfuryl- $N$-imidazol- 1 -ylcarbonyl-DL-homoalaninate) is a new fungicide developed by UBE Industries, Ltd. and Hokko Chemical Industry Co., Ltd. It is used for control of seed-borne pathogens of rice, e.g. Gibberella fujikuroi, Cochliobolus miyabeanus, and Pyricularia oryzae. ${ }^{1)}$ Its antifungal action is considered to be the inhibition of ergosterol biosynthesis similar to that of the related azole fungicides. ${ }^{2)}$

Rice seeds disinfected with pefurazoate by soaking or spraying are cultured in nursery soil for three weeks, and the seedlings are transplanted in paddy fields. In this process pefurazoate may be transferred into paddy soil along with rice seeds.

In the present paper, the degradation and adsorption of pefurazoate in the soil were investigated.

* To whom all correspondence should be addressed.

\section{MATERIALS AND METHODS}

\section{Chemicals}

${ }^{14} \mathrm{C}$-Pefurazoate (Fig. 1) was synthesized from [methyl- ${ }^{14} \mathrm{C}$ ]-2-aminomethylfuran (specific activity: $1.43 \mathrm{GBq} / \mathrm{mmol}$, radiochemical purity: $98.5 \%$ ) purchased from CEA as a starting ${ }^{14} \mathrm{C}$-labeled compound by three steps: A mixture of $\left[\right.$ methyl $\left.-{ }^{14} \mathrm{C}\right]$-2-aminomethylfuran $(0.65$ mmol), pent-4-enyl (RS)-2-bromobutanoate $(1.95 \mathrm{mmol})$ and sodium carbonate $(0.65 \mathrm{mmol})$ was refluxed in acetonitrile for $15 \mathrm{hr}$, and the crude product was purified to obtain pent-4enyl $\quad N-{ }^{14} \mathrm{C}$-furfuryl-DL-homoalaninate $\quad(0.55$ mmol) with a silica gel column. It was then stirred at room temperature for $6 \mathrm{hr}$ with triethylamine $(0.83 \mathrm{mmol})$ and trichloromethyl chloroformate $(0.83 \mathrm{mmol})$ in toluene. The mixture was extracted with toluene after being quenched with water, and the toluene solution was treated at $65-70^{\circ} \mathrm{C}$ for $4 \mathrm{hr}$ with triethylamine $(0.98 \mathrm{mmol})$ and imidazole (1.95 mmol) to obtain ${ }^{14} \mathrm{C}$-pefurazoate $(0.41 \mathrm{mmol})$.

The chemical structure of ${ }^{14} \mathrm{C}$-pefurazoate 
Table $1 R_{f}$ values of pefurazoate and its degradation products by TLC.

\begin{tabular}{|c|c|c|c|c|c|c|c|c|c|c|c|}
\hline \multirow{2}{*}{ No. } & \multirow{2}{*}{ Solvent system } & \multirow{2}{*}{$\begin{array}{l}\text { Volume } \\
\text { ratio }\end{array}$} & \multicolumn{9}{|c|}{ Compounds } \\
\hline & & & Pefurazoate & PFAB & $\mathrm{FAB}$ & $\mathrm{HPB}$ & FG & M-1 & $\mathrm{M}-2$ & M-3 & M-4 \\
\hline 1 & $\mathrm{CHCl}_{3} / \mathrm{EtOH} / 28 \% \mathrm{NH}_{4} \mathrm{OH}$ & $2: 4: 1$ & 0.89 & 0.89 & 0.53 & 0.28 & 0.44 & 0.92 & 0.80 & 0.72 & 0.49 \\
\hline 2 & $n-\mathrm{BuOH} / \mathrm{AcOH} / \mathrm{H}_{2} \mathrm{O}$ & $5: 1: 1$ & 0.79 & 0.62 & 0.32 & 0.20 & 0.49 & - & - & - & - \\
\hline 3 & AcOEt/MeOH/HCOOH & $8: 8: 1$ & 0.76 & 0.78 & 0.42 & - & 0.82 & - & - & - & - \\
\hline 4 & $\mathrm{C}_{6} \mathrm{H}_{5} \mathrm{CH}_{3} / \mathrm{AcOEt}$ & $1: 5$ & 0.32 & 0.59 & 0.00 & 0.00 & 0.01 & - & - & - & - \\
\hline 5 & AcOEt/MeOH/HCOOH & $10: 5: 1$ & 0.90 & - & 0.30 & 0.08 & 0.64 & - & - & - & - \\
\hline 6 & $n-\mathrm{PrOH} / 28 \% \mathrm{NH}_{4} \mathrm{OH}$ & $2: 1$ & 0.81 & - & - & 0.04 & - & - & - & - & - \\
\hline 7 & $n-\mathrm{C}_{6} \mathrm{H}_{12} / \mathrm{AcOEt}$ & $4: 1$ & 0.02 & 0.32 & - & - & - & - & - & - & - \\
\hline
\end{tabular}

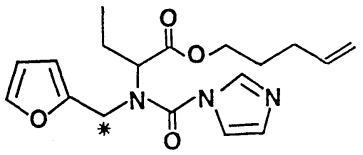

Fig. 1 Chemical structure of pefurazoate. * labeled position.

was confirmed by EI-mass spectrometry (M80A, Hitachi) [MS $m / z: 347\left(\mathrm{M}^{+}\right), 252\left(\mathrm{M}^{+}\right.$ timidazolylcarbonyl $), 192\left(\mathrm{M}^{+}\right.$-pentenyl buanoate), 83 ( $\mathrm{M}^{+}$-pentenyl $(N$-imidazolylcarbonyl)homoalaninate)]. The radiochemical purity was more than $97 \%$ by TLC (silica gel plate, $60 \mathrm{~F}_{254}, 20 \times 20 \mathrm{~cm}, 0.25 \mathrm{~mm}$ thickness, Merck) with solvent systems 2 and 4 shown in Table 1 .

Unlabeled authentic pefurazoate and four reference compounds (PFAB, * FAB, * $\left.\mathrm{HPB},{ }^{* 3}\right)$ $\left.\mathrm{FG}^{*}\right)$ were prepared as follows, and the chemical structures of them were confirmed by ${ }^{1} \mathrm{H}$ NMR (200 MHz, JASCO).

Pefurazoate was synthesized by the same method used in the synthesis of ${ }^{14} \mathrm{C}$-pefurazoate $\left[{ }^{1} \mathrm{H}\right.$ NMR $\delta_{\mathrm{TMS}}^{\mathrm{CDCl}_{3}} \mathrm{ppm}: 0.8(3 \mathrm{H}, t, J=$ $\left.7.2 \mathrm{~Hz}, \mathrm{CH}_{2} \mathrm{CH}_{3}\right), 1.7-1.8\left(2 \mathrm{H}, m, \mathrm{CH}_{2} \mathrm{CHCH}_{2-}\right.$ $\left.\mathrm{CH}_{2} \mathrm{CH}_{2} \mathrm{O}\right), \quad 2.0-2.2\left(4 \mathrm{H}, m, \quad \mathrm{CH}_{3} \mathrm{CH}_{2}, \mathrm{CH}_{2}-\right.$ $\left.\mathrm{CHCH}_{2} \mathrm{CH}_{2} \mathrm{CH}_{2} \mathrm{O}\right), \quad 4.0 \quad(1 \mathrm{H}, d d, \quad \bar{J}=9.4 \mathrm{~Hz}$, $5.8 \overline{\mathrm{Hz}}, \quad \mathrm{NCHCO}), \quad 4.2(2 \mathrm{H}, \quad t, J=6.6 \mathrm{~Hz}$, $\left.\mathrm{CH}_{2} \mathrm{CHCH}_{2} \mathrm{CH}_{2} \mathrm{CH}_{2} \mathrm{O}\right), 4.5(1 \mathrm{H}, d, J=16.4 \mathrm{~Hz}$, 2-furylmethyl), $\overline{4.7}(1 \mathrm{H}, \quad d, J=16.4 \mathrm{~Hz}, 2$ furylmethyl), 5.0-5.1 (2H, $m, \mathrm{CH}_{2} \mathrm{CHCH}_{2} \mathrm{CH}_{2}-$ $\left.\mathrm{CH}_{2} \mathrm{O}\right), 5.8\left(1 \mathrm{H}, m, \mathrm{CH}_{2} \mathrm{CHCH}_{2} \overline{\mathrm{CH}}_{2} \mathrm{CH}_{2} \mathrm{O}\right), 6.4$

* PFAB, pent-4-enyl $N$-furfuryl-DL-homoalaniate; FAB, $N$-furfuryl-DL-homoalanine; HPB, 1-((RS)1-carboxylatopropyl)-3-hydroxypyridinium; FG, $N$-(furan-2-ylcarbonyl)glycine
(2H, $m$, furan), $7.1(1 \mathrm{H}, d$, imidazole), $7.5(1 \mathrm{H}$, $d$, furan), $7.5(1 \mathrm{H}, d$, imidazole $), 8.1(1 \mathrm{H}, s$, imidazole)].

PFAB: Furfurylamine was treated with methyl (RS)-2-bromobutanoate following the ester exchange with 4-pentenol $\left[{ }^{1} \mathrm{H}\right.$ NMR $\delta_{\mathrm{TMS}}^{\mathrm{CDCl}_{3}} \mathrm{ppm}: 0.9\left(3 \mathrm{H}, t, J=7.2 \mathrm{~Hz}, \mathrm{CH}_{2} \mathrm{CH}_{3}\right)$, 1.7-1.8 (4H, $m, \mathrm{CH}_{2} \mathrm{CH}_{3}, \mathrm{CH}_{2} \mathrm{CHCH}_{2} \mathrm{CH}_{2} \overline{\mathrm{CH}}_{2}-$ O), $1.9(1 \mathrm{H}, s, \overline{\mathrm{NH}}), \quad 2.1-2.2$ (2H. $m, \mathrm{CH}_{2}-$ $\left.\mathrm{CHCH}_{2} \mathrm{CH}_{2} \mathrm{CH}_{2} \mathrm{O}\right), \quad 3.2(1 \mathrm{H}, \quad t, \quad J=6.4 \mathrm{~Hz}$, $\mathrm{NCHCO}), 3.8(2 \mathrm{H}, d, J=14.2$, 2-furylmethyl), $4.1-\left(2 \mathrm{H}, t, J=6.6 \mathrm{~Hz}, \mathrm{CH}_{2} \mathrm{CHCH}_{2} \mathrm{CH}_{2} \mathrm{CH}_{2} \mathrm{O}\right)$, $5.0\left(2 \mathrm{H}, m, \mathrm{CH}_{2} \mathrm{CHCH}_{2} \mathrm{CH}_{2} \mathrm{CH}_{2} \mathrm{O}\right), 5.8(1 \overline{\mathrm{H}}, m$, $\mathrm{CH}_{2} \mathrm{CHCH}_{2} \mathrm{CH}_{2} \mathrm{CH}_{2} \mathrm{O}$ ), 6.2 (1H, $d$, furan), 6.3 (1H, $\overline{d d}$, furan), $7.3(1 \mathrm{H}, d$, furan)].

FAB: Methyl $N$-furfuryl-DL-homoalaninate prepared by the above-mentioned route was hydrolyzed with alkali and neutralized with hydrochloric acid $\left[{ }^{1} \mathrm{H}\right.$ NMR $\delta_{\mathrm{TM}}^{\mathrm{D}_{2} \mathrm{O}}$ ppm: $1.0(3 \mathrm{H}$, $\left.t, J=7.2 \mathrm{~Hz}, \mathrm{CH}_{3} \mathrm{CH}_{2}\right), 1.9\left(2 \mathrm{H}, m, \mathrm{CH}_{3} \mathrm{CH}_{2}\right)$, $3.6\left(1 \mathrm{H}, t, J=\overline{6.4}, \mathrm{CH}_{3} \mathrm{CH}_{2} \mathrm{CH}\right), 4.3(2 \overline{\mathrm{H}}, d$, 2-furylmethyl), $6.5(1 \mathrm{H}, d, J=3.6$, furan), 6.6 $(1 \mathrm{H}, d \overline{d, \text { furan }),} 7.6(1 \mathrm{H}, d, J=2.0$, furan $)]$.

HPB: (RS)-1-(1-carboxylatopropyl)-3-hydroxypyridinium bromide prepared by the reaction of 3-hydroxypyridine with 2-bromobutanoic acid was treated with sodium hydroxide $\left[{ }^{1} \mathrm{H}\right.$ NMR $\delta_{\text {TM }}^{\mathrm{D}_{2} \mathrm{O}} \mathrm{ppm}: 0.9(3 \mathrm{H}, t, J=$ $\left.7.2 \mathrm{~Hz}, \mathrm{CH}_{3} \mathrm{CH}_{2}\right), 2.1\left(1 \mathrm{H}, m, \mathrm{CH}_{3} \mathrm{CH}_{2}\right), 2.4$ $\left(1 \mathrm{H}, m, \mathrm{CH}_{3} \mathrm{CH}_{2}\right), 4.8\left(4 \mathrm{H}, d d, \mathrm{CH}_{3} \mathrm{CH}_{2} \overline{\mathrm{CHCO}}\right)$, $7.5(1 \mathrm{H}, m$, pyrimidine $), 7.6(1 \mathrm{H}, m$, pyrimidine), $7.7(1 \mathrm{H}, m$, pyrimidine), $7.8(1 \mathrm{H}, m$, pyrimidine)].

FG: Ethyl $N$-(furan-2-ylcarbonyl)glycinate prepared by the reaction of furoyl chloride with ethyl glycinate was hydrolyzed with alkali and neutralized with hydrochloric acid 
Table 2 Physicochemical properties of soil samples used.

\begin{tabular}{lllcccrr}
\hline Location & $\begin{array}{c}\text { Parent } \\
\text { material }\end{array}$ & Texture & $\begin{array}{c}\text { Clay } \\
\text { content }(\%)\end{array}$ & $\begin{array}{c}\text { Organic } \\
\text { carbon }(\%)\end{array}$ & $\begin{array}{c}\text { Total } \\
\text { nitrogen }(\%)\end{array}$ & $\begin{array}{c}\mathrm{CEC} \\
(\mathrm{mEq} / 100 \mathrm{~g})\end{array}$ & $\begin{array}{c}\mathrm{pH} \\
\left(\mathrm{H}_{2} \mathrm{O}\right)\end{array}$ \\
\hline Yamaguchi & Alluvial & $\mathrm{SL}$ & 22.3 & 1.8 & 0.17 & 8.6 & 5.5 \\
Ushiku & Volcanic ash & $\mathrm{LiC}$ & 37.7 & 5.7 & 0.42 & 31.5 & 6.1 \\
\hline
\end{tabular}

$\left[{ }^{1} \mathrm{H}\right.$ NMR $\delta_{\mathrm{TMS}}^{\mathrm{CD}_{3} \mathrm{OD}} \mathrm{ppm}: 4.1 \quad\left(2 \mathrm{H}, \quad s, \mathrm{NHCH}_{2}\right.$ COOH), $6.6(1 \mathrm{H}, d$, furan), $7.1(1 \mathrm{H}, d d$, furan $)$, $7.7(1 \mathrm{H}, d$, furan)].

\section{Soil}

The physicochemical properties of Yamaguchi and Ushiku paddy soils are shown in Table 2. Soil samples were air-dried and sieved under $2 \mathrm{~mm}$. The soils were sterilized with an intermittent autoclave at $120^{\circ} \mathrm{C}$ and $2 \mathrm{~atm}$ for $30 \mathrm{~min}$ every day for three days.

\section{Degradation Test}

\subsection{Unaerated condition}

Air-dried soil (25 g dry weight) was preincubated in a 100-ml Erlenmeyer flask at $28^{\circ} \mathrm{C}$ for a week under a flooded condition with water $1 \mathrm{~cm}$ deep. After preincubation, $1 \mathrm{ml}$ aqueous solution containing $25 \mu \mathrm{g}{ }^{14} \mathrm{C}$-pefurazoate $\left(1.04 \times 10^{-1} \mathrm{MBq}, 1 \mathrm{ppm}\right.$ per soil) was injected into Yamaguchi and Ushiku soils and incubated at $28^{\circ} \mathrm{C}$ in the dark.

\subsection{Aerated condition}

This test was carried out to examine volatile compounds evolving during incubation. Airdried soil was incubated aerated with a current of wet air $(5 \mathrm{ml} / \mathrm{min})$ by the same method as described in Unaerated Condition except for the use of an incubation apparatus. ${ }^{4}$ Volatile ${ }^{14} \mathrm{C}$-compounds were trapped with two sequential bottles containing $10 \mathrm{ml}$ of $10 \%$ $\mathrm{NaOH}$ aqueous solution. The solution was renewed every week. In this experiment, the recovery of the radioactivity from the soils was satisfactory (recovery ratio: $97.8 \%$ in the Yamaguchi soil and $92.3 \%$ in the Ushiku soil 8 weeks after application). ${ }^{14} \mathrm{CO}_{2}$ in the $\mathrm{NaOH}$ solution was determined from the radioactivity in the solution before and after treatment with $1 \mathrm{M} \mathrm{BaCl}_{2}$ solution that was used to remove ${ }^{14} \mathrm{CO}_{2}$.

\section{Analytical Method}

Flooded water (flooded-water fraction) separated by centrifugation $(10,000 \mathrm{rpm}, 10$ min) was lyophilized and dissolved with $3 \mathrm{ml}$ of methanol.

The soil separated from the flooded water was shaken for $1 \mathrm{hr}$ twice with $50 \mathrm{ml}$ of $30 \%$ aqueous acetone solution. This extract (acetone-water-extractable fraction) was concentrated to dryness in vacuo below $40^{\circ} \mathrm{C}$ and dissolved with $3 \mathrm{ml}$ of methanol.

The residues were subjected to refluxing for $2 \mathrm{hr}$ with methanol. This extract (hotmethanol-extractable fraction) was concentrated in vacuo to $3 \mathrm{ml}$ solution. The unextracted precipitate was classified as bound residue fraction.

Each fraction except the bound residue was analyzed by TLC. Individual solutions (10$100 \mu \mathrm{l})$ were spotted on silica gel plates and developed with solvent systems 1 and 4 as shown in Table $1 .{ }^{14} \mathrm{C}$-Compounds separated on the plates were detected by autoradiography $\left({ }^{3} \mathrm{H}\right.$ ARG film, Konica) and determined by liquid scintillation spectrometry (LSC, Tri-carb 2000 CA, Packard) with a Clear-Sol scintillator (Nakarai Chemical). The degradation products were identified by TLC co-chromatography with reference compounds.

Bound residue was extracted by shaking with $75 \mathrm{ml}$ of $0.5 \mathrm{~m} \mathrm{NaOH}$ solution for $18 \mathrm{hr}$ at room temperature. The unextracted precipitate was classified as humin fraction. The extract was separated to two fractions by adjusting its $\mathrm{pH}$ to 1.0: The supernatant to a fulvic acid fraction and the precipitate to a humic acid fraction. The radioactivity in the supernatant fraction was determined by LSC and that in the total bound residue and the humin fraction was determined by LSC after treatment with an autocombution system (ASC-113, Aloka). The radioactivity in the 
humic acid fraction was calculated by subtracting the radioactivity in the fulvic acid and the humin fraction from that in the bound residue fraction.

\section{Adsorption and Desorption Test ${ }^{5,6)}$ \\ 5.1 Adsorption equilibrium time}

Yamaguchi or Ushiku soil (2 $\mathrm{g}$ dry weight) was shaken reciprocally at 160 rounds $/ \mathrm{min}$ in a polypropylene $100-\mathrm{ml}$ centrifuging tube for 4,24 and $48 \mathrm{hr}$ at $25^{\circ} \mathrm{C}$ with $10 \mathrm{ml}$ of $10^{-2} \mathrm{M}$ $\mathrm{CaCl}_{2}$ solution containing $25 \times 10^{-6} \mathrm{M}{ }^{14} \mathrm{C}$ pefurazoate $(35.6 \mathrm{kBq}, 43.1 \mathrm{ppm}$ per soil) (solubility of pefurazoate in water: $1.25 \times 10^{-3}$ $\mathrm{M})$. The unadsorbed radioactivity in the supernatant, which was separated by centrifugation $(19,000 \mathrm{~g}, 15 \mathrm{~min})$ from the soil suspension, was determined by LSC. The concentration of pefurazoate in the equilibrium solution could be calculated from the measured radioactivity, since the result of TLC analysis of ${ }^{14} \mathrm{C}$-compounds in the supernatant showed that most of pefurazoate in the supernatant remained undegraded (degradation ratio: 6.2\% in the Yamaguchi soil and 5.8\% in the Ushiku soil).

\subsection{Adsorption and desorption coefficient}

Soils were shaken with $10^{-2} \mathrm{M} \mathrm{CaCl}_{2}$ solution containing pefurazoate at four different concentrations $(0.345,1.73,8.63,43.1 \mathrm{ppm}$ per soil) for $24 \mathrm{hr}$ by the same method as previously mentioned. After shaking, $8 \mathrm{ml}$ of the supernatant obtained by centrifugation was removed and the radioactivity was determined. Subsequently to measure the desorption coefficient, $8 \mathrm{ml}$ of fresh $10^{-2} \mathrm{M} \mathrm{CaCl}_{2}$ solution was added to the soil suspension. After shaking for $24 \mathrm{hr}$, the desorbed radioactivity in the supernatant was determined. The concentration of pefurazoate in the desorption equilibrium solution was calculated from the measured radioactivity, since few degradation products were found in the desorbed solution. These tests were also carried out with sterilized soils in which pefurazoate was not degraded.

Freudlich adsorption coefficient $\left(K_{\mathrm{f}}\right)$ and adsorption exponent $(1 / n)$ were calculated with the following equation:

$$
\log C_{\mathrm{s}}=\log K_{\mathrm{f}}+1 / n \log C_{\mathrm{e}}
$$

$C_{\mathrm{s}}$ : equilibrium concentration of pefurazoate in the solid phase (ppm) $=$ (added pefurazoate - pefurazoate in

the equilibrium solution)/soil weight

$C_{\ominus}$ : equilibrium concentration of pefurazoate in the solution phase (ppm)

While $K_{\mathrm{f}}$ and $1 / n$ of desorption were calculated, $C_{\mathrm{s}}$ was determined as follows:

$C_{\mathrm{s}}=($ adsorbed pefurazoate in the adsorption-equilibrium solution + unremoved pefurazoate in the adsorption-equilibrium solutionpefurazoate in the desorptionequilibrium solution)/soil weight

\section{RESULTS AND DISCUSSION}

\section{Degradation of Pefurazoate}

\subsection{Distribution of radioactivity (Fig. 2)}

Total radioactivity remaining in the Yamaguchi soil gradually decreased to $36.9 \%$ of the dose after 14 weeks' incubation. The floodedwater fraction accounted for over $10 \%$ of the dose in the early period of incubation, and then it decreased to 2.0 and $0.2 \%$ after 6 and 14 weeks, respectively. In the acetone-waterextractable fraction, nearly $80 \%$ of the dose was recovered in the early period, but the recovery decreased to $11.3 \%$ after 14 weeks. The fate of this fraction corresponded with that of the total radioactivity. The hotmethanol-extractable fraction increased gradually to $12.3 \%$ (maximum) during the first four weeks. The radioactivity in the bound residue fraction increased to $21.4 \%$ during the first six weeks, but decreased to $18.8 \%$ during the last eight weeks.

Almost the same results were found in the Ushiku soil. However, there was a slight difference the radioactivity of the floodedwater fraction in the Ushiku soil was lower than that of it in the Yamaguchi soil during the first four weeks and that of the hotmethanol-extractable fraction was always lower.

\subsection{Fate of pefurazoate and its degradation products (Table 3)}

In the Yamaguchi soil pefurazoate was degraded to $51.7 \%$ during the first three days, but it gradually decreased to $13.9 \%$ during the following six weeks. Similarly in the Ushiku soil it decreased to $56.3 \%$ during the 


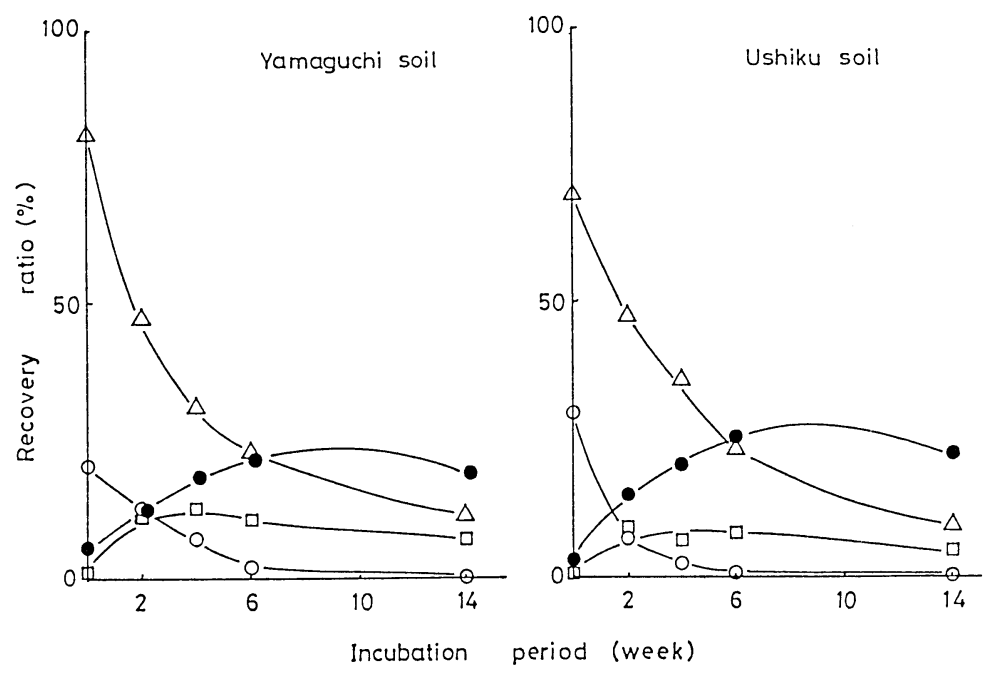

Fig. 2 Distribution of radioactivity in paddy soil.

$\bigcirc$ : flooded-water, $\Delta$ : acetone-water, $\square$ : hot-methanol,

- : bound residue.

Table 3 Fate of pefurazoate and its degradation products.

(recovery ratio, \%)

\begin{tabular}{|c|c|c|c|c|c|c|}
\hline \multirow{2}{*}{ Soil } & \multirow{2}{*}{$\begin{array}{c}\text { Detected } \\
\text { compounds }\end{array}$} & \multicolumn{5}{|c|}{ Incubation period (day) } \\
\hline & & 0 & 3 & 14 & 28 & 42 \\
\hline \multirow[t]{12}{*}{ Yamaguchi } & Pefurazoate & 86.5 & 51.7 & 22.8 & 18.6 & 13.9 \\
\hline & PFAB & 2.7 & 7.1 & 8.4 & 4.7 & 2.7 \\
\hline & FAB & 1.6 & 8.8 & 12.1 & 7.5 & 2.7 \\
\hline & FG & 0.6 & 0.5 & 0.8 & 0.6 & 0.5 \\
\hline & $\mathrm{HPB}$ & 0.0 & 1.2 & 1.5 & 0.8 & 2.0 \\
\hline & $\mathrm{M}-1$ & $<0.1$ & 0.7 & 1.9 & 1.8 & 0.8 \\
\hline & M-2 & 1.0 & 4.2 & 6.8 & 5.4 & 2.7 \\
\hline & M-3 & 1.2 & 2.3 & 3.3 & 3.0 & 2.1 \\
\hline & M-4 & 1.6 & 0.8 & 1.3 & 1.1 & 0.8 \\
\hline & Others $\left.^{a}\right)$ & 6.6 & 15.9 & 11.8 & 7.2 & 7.1 \\
\hline & Bound residue & 5.3 & 6.8 & 12.1 & 18.1 & 21.4 \\
\hline & Total & 107.1 & 100.0 & 82.8 & 68.8 & 56.7 \\
\hline \multirow[t]{12}{*}{ Ushiku } & Perfurazoate & 87.8 & 56.3 & 38.0 & 16.9 & 16.8 \\
\hline & PFAB & 2.1 & 5.4 & 3.7 & 4.3 & 2.0 \\
\hline & FAB & 0.7 & 5.4 & 6.7 & 2.7 & 1.0 \\
\hline & FG & 0.4 & 0.4 & 0.8 & 0.7 & 0.4 \\
\hline & $\mathrm{HPB}$ & 0.0 & 0.9 & 0.8 & 0.7 & 0.6 \\
\hline & M-1 & 0.0 & 1.6 & 1.5 & 1.7 & 0.9 \\
\hline & M-2 & 1.3 & 4.5 & 3.1 & 6.2 & 2.6 \\
\hline & M-3 & 0.2 & 2.1 & 1.7 & 3.2 & 1.4 \\
\hline & M-4 & $<0.1$ & 0.8 & 0.7 & 1.6 & 0.6 \\
\hline & Others $\left.^{a}\right)$ & 6.7 & 11.9 & 6.0 & 6.2 & 5.2 \\
\hline & Bound residue & 3.0 & 8.0 & 14.6 & 20.2 & 25.3 \\
\hline & Total & 102.2 & 97.4 & 77.6 & 64.4 & 56.8 \\
\hline
\end{tabular}

a) Others contain many minor degradation products. 
first three days and to $16.8 \%$ during the following six weeks. Thus, pefurazoate was easily degraded to half within a week, but the rate of degradation afterward was fairly slow.

Several degradation products were found by TLC in the flooded-water, acetone-water-extractable, and hot-methanol-extractable fractions. Of these major products, PFAB, FAB, HPB and FG were identified by TLC cochromatography with several solvent systems as shown in Table 1, whereas other products (M-1, -2, -3 and -4) were failed to be identified. The accumulation ratio of each degradation product was less than $10 \%$ of the dose, being in the following order: PFAB, FAB, M-2> M-3>FG, HPB, M-1, M-4.

From these degradation products, a degradation pathway is proposed as in Fig. 3; The degradation of pefurazoate started with elimination of the azolylcarbonyl group to produce $\mathrm{PFAB}$, or hydrolysis of cster and additional elimination to yield $\mathrm{FAB}$ via an unidentified intermediate. PFAB also released $\mathrm{FAB}$, which then yielded-FG and HPB. The former transformation was caused by the decarboxylation of $\omega$ and $\omega-1$ carbons of the carboxylate moiety and the oxidation of furfuryl carbon. ${ }^{7,8)}$ The latter was by the condensation reaction between amine-nitrogen of $\mathrm{FAB}$ and the reactive position-5 carbon derived from cleavage of the bond between position-5 carbon and oxygen in the furan ring of $\mathrm{FAB}$.

Unextractable bound residues (fulvic acid, humin and humic acid fractions) increased to $21.4 \%$ of the dose in the Yamaguchi soil and $25.3 \%$ in the Ushiku soil after 42 days' incubation. Of these fractions, fulvic acid, humin and humic acid fraction occupied 59.3\%,
$35.2 \%$ and $5.6 \%$, respectively in the Yamaguchi soil, while in the Ushiku soil $40.6 \%$, $56.6 \%$ and $2.8 \%$, respectively. The ratio of organic ${ }^{14} \mathrm{C}$ fractions (fulvic acid, humin and humic acid) found in the present study was quite different from that of the original soil organic carbon (fulvic acid: $42.6 \%$, humin: $2.7 \%$, humic acid: $54.7 \%$ in the Yamaguchi soil)..$^{9)}$

Under the unsterilized condition, the volatile ${ }^{14} \mathrm{C}$ trapped with alkali solution amounted to $36.4 \%$ of the dose in the Yamaguchi soil and $30.9 \%$ in the Ushiku soil during eight weeks, and more than $95 \%$ of the trapped ${ }^{14} \mathrm{C}-\mathrm{com}$ -

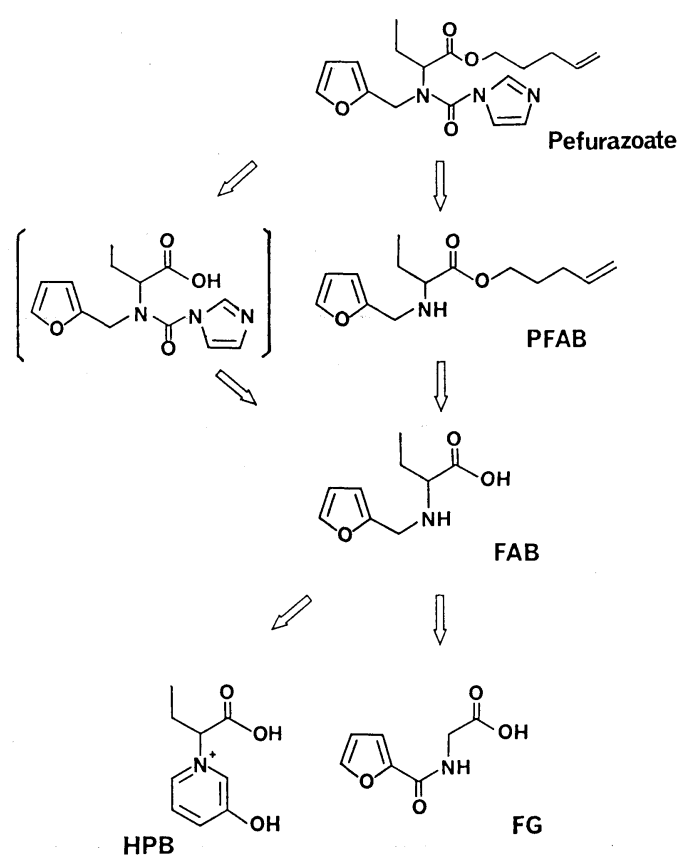

Fig. 3 Proposed degradation pathway of pefurazoate in paddy soil.

Table 4 Volatile degradation products evolved from soil.

(\% of dose)

\begin{tabular}{clrrrrr}
\hline \multirow{2}{*}{ Treatment } & \multirow{2}{*}{ Soil } & \multicolumn{5}{c}{ Incubation period (week) } \\
\cline { 3 - 7 } & & 1 & 2 & 3 & 5 & 8 \\
\hline \multirow{2}{*}{ Unsterilized } & Yamaguchi & 5.0 & 11.2 & 15.5 & 22.4 & 36.4 \\
\multirow{2}{*}{ Sterilized } & Ushiku & 2.9 & 6.8 & 11.5 & 19.8 & 30.9 \\
& Yamaguchi & 0.0 & 0.0 & 0.0 & 0.1 & - \\
& Ushiku & 0.1 & 0.2 & 0.3 & 0.5 & - \\
\hline
\end{tabular}


pounds consisted of ${ }^{14} \mathrm{CO}_{2}$. Under the sterilized condition, however, there was almost no trapped ${ }^{14} \mathrm{C}$ (less than $0.5 \%$ of the dose) in both soils as shown in Table 4 . Thus, the microbial action was much involved in the degradation of pefurazoate.

\section{Adsorption and Desorption}

\subsection{Adsorption equilibrium time}

The adsorption amount during an additional 24-hr shaking increased to $0.6 \%$ in the Yamaguchi soil and $2.6 \%$ in the Ushiku soil under the unsterilized condition, while under the sterilized condition $3.8 \%$ in the Yamaguchi soil and $2.8 \%$ in the Ushiku soil. Thus, the adsorption equilibrium was attained during the first 24-hr shaking since there was only a slight increase of adsorption amount during the following 24-hr saking.

\subsection{Freundlich constants}

Adsorption and desorption equilibria of pefurazoate are shown in Tables 5 and 6.

The property of soil adsorption of pefurazoate was examined under the unsterilized and sterilized conditions since pefurazoate was degraded only slightly (about $6 \%$ of the application) under the unsterilized condition.

Under both conditions, the correlation between the concentration of pefurazoate in the equilibrium solution and in the soil was high $(\gamma>0.99)$, therefore it was considered that pefurazoate was adsorbed in accordance with the Freundlich adsorption isotherm.

The Freundlich constants are shown in Table 7.

The Freundlich adsorption coefficient was 16.3 in the Yamaguchi soil and 21.9 in the Ushiku soil under the unsterilized condition, while under the sterilized condition 11.8 in the Yamaguchi soil and 17.5 in the Ushiku soil. The desorption coefficient was 21.1 in the Yamaguchi soil and 25.2 in the Ushiku soil under the unsterilized condition, while under the sterilized condition 21.4 in the Yamaguchi soil and 23.2 in the Ushiku soil. Thus the Freundlich adsorption coefficient was not much affected by soil sterilization. It was considered that soil sterilization had reduced the Freundlich adsorption coefficient by inducing soil organic matter acting as an ad-

Table 5 Adsorption equilibrium.

\begin{tabular}{|c|c|c|c|c|c|}
\hline \multirow{2}{*}{ Treatment } & \multirow{2}{*}{ Soil } & \multirow{2}{*}{$\begin{array}{l}\text { Concentration } \\
\text { of pefurazoate } \\
\text { added to soil } \\
\qquad(\mathrm{ppm})\end{array}$} & \multicolumn{2}{|c|}{$\begin{array}{l}\text { Equilibrium conc. of pefurazoate } \\
\qquad(\mathrm{ppm})\end{array}$} & \multirow{2}{*}{$\begin{array}{l}\text { Adsorption } \\
\text { ratio } \\
\left(K_{\mathrm{d}}\right)^{\text {a }}\end{array}$} \\
\hline & & & Solution & Soil & \\
\hline \multirow[t]{8}{*}{ Unsterilized } & Yamaguchi & 0.0690 & 0.00845 & 0.300 & 35.5 \\
\hline & & 0.345 & 0.0465 & 1.49 & 32.0 \\
\hline & & 1.725 & 0.301 & 6.98 & 23.2 \\
\hline & & 8.625 & 2.43 & 30.1 & 12.4 \\
\hline & Ushiku & 0.0690 & 0.00411 & 0.321 & 78.1 \\
\hline & & 0.345 & 0.0271 & 1.58 & 58.3 \\
\hline & & 1.725 & 0.210 & 7.38 & 35.1 \\
\hline & & 8.625 & 1.88 & 32.4 & 17.2 \\
\hline \multirow[t]{8}{*}{ Sterilized } & Yamaguchi & 0.0690 & 0.0120 & 0.280 & 23.3 \\
\hline & & 0.345 & 0.0656 & 1.37 & 20.9 \\
\hline & & 1.725 & 0.430 & 6.34 & 14.7 \\
\hline & & 8.625 & 3.06 & 27.6 & 9.0 \\
\hline & Ushiku & 0.0690 & 0.00755 & 0.301 & 39.9 \\
\hline & & 0.345 & 0.0435 & 1.47 & 33.8 \\
\hline & & 1.725 & 0.293 & 6.97 & 23.8 \\
\hline & & 8.625 & 2.22 & 31.3 & 14.1 \\
\hline
\end{tabular}

a) $K_{\mathrm{d}}=$ (concentration of pefurazoate in soil)/(concentration of pefurazoate in solution)

Remark: Data are average of duplicates. 
Table 6 Desorption equilibrium.

\begin{tabular}{|c|c|c|c|c|c|}
\hline \multirow[t]{2}{*}{ Treatment } & \multirow{2}{*}{ Soil } & \multirow{2}{*}{$\begin{array}{l}\text { Concentration } \\
\text { of pefurazoate } \\
\text { added to soil } \\
(\mathrm{ppm})\end{array}$} & \multicolumn{2}{|c|}{$\begin{array}{l}\text { Equilibrium conc. of perfurazoate } \\
\qquad(\mathrm{ppm})\end{array}$} & \multirow{2}{*}{$\begin{array}{l}\text { Adsorption } \\
\text { ratio } \\
\left(K_{\mathrm{d}}\right)^{\mathrm{a})}\end{array}$} \\
\hline & & & Solution & Soil & \\
\hline \multirow[t]{8}{*}{ Unsterilized } & Yamaguchi & 0.0690 & 0.00525 & 0.283 & 53.9 \\
\hline & & 0.345 & 0.0301 & 1.38 & 45.8 \\
\hline & & 1.725 & 0.196 & 6.31 & 32.2 \\
\hline & & 8.625 & 1.43 & 25.5 & 17.8 \\
\hline & Ushiku & 0.0690 & 0.00291 & 0.311 & 106.9 \\
\hline & & 0.345 & 0.0194 & 1.51 & 77.8 \\
\hline & & 1.725 & 0.154 & 6.85 & 44.5 \\
\hline & & 8.625 & 1.29 & 28.1 & 21.8 \\
\hline \multirow[t]{8}{*}{ Sterilized } & Yamaguchi & 0.0690 & 0.00627 & 0.261 & 41.6 \\
\hline & & 0.345 & 0.0342 & 1.27 & 37.1 \\
\hline & & 1.725 & 0.191 & 5.84 & 30.6 \\
\hline & & 8.625 & 1.33 & 24.2 & 18.2 \\
\hline & Ushiku & 0.0690 & 0.00463 & 0.286 & 61.8 \\
\hline & & 0.345 & 0.0271 & 1.39 & 51.3 \\
\hline & & 1.725 & 0.180 & 6.41 & 35.6 \\
\hline & & 8.625 & 1.33 & 27.2 & 20.5 \\
\hline
\end{tabular}

a) $K_{\mathrm{d}}=$ (concentration of pefurazoate in soil)/(concentration of pefurazoate in solution).

Remark: Data are average of duplicates.

Table 7 Freundlich constants.

\begin{tabular}{|c|c|c|c|c|c|c|}
\hline \multirow{2}{*}{ Treatment } & \multirow{2}{*}{ Soil } & \multicolumn{2}{|c|}{ Adsorption } & \multicolumn{2}{|c|}{ Desorption } & \multirow{2}{*}{$\Delta K(\%)^{\mathrm{c})}$} \\
\hline & & $K_{\mathrm{f}}^{\mathrm{a}}{ }^{\mathrm{a}}$ & $\left.1 / n^{\mathrm{b}}\right)$ & $K_{\mathrm{f}}$ & $1 / n$ & \\
\hline \multirow[t]{2}{*}{ Unsterilized } & Yamaguchi & 16.3 & 0.813 & 21.1 & 0.803 & 29.4 \\
\hline & Ushiku & 21.9 & 0.752 & 25.2 & 0.738 & 15.1 \\
\hline \multirow[t]{2}{*}{ Sterilized } & Yamaguchi & 11.8 & 0.827 & 21.4 & 0.848 & 81.3 \\
\hline & Ushiku & 17.5 & 0.815 & 23.2 & 0.803 & 32.6 \\
\hline
\end{tabular}

a) Freundlich adsorption or desorption coefficient.

b) Adsorption or desorption exponent.

c) Percentage change in the $K_{\mathrm{f}}$ values in going from adsorption to desorption.

sorbent to decompose, while it had raised the Freundlich adsorption coefficient by preventing pefurazoate from transforming into more hydrophilic compounds which were less adsorbed by the soil organic matter.

Pefurazoate was not tightly adsorbed compared with some marketed pesticides (paraquat, 202; linuron, 45.1 ; atrazine, 56.3$)^{10,11)}$ in terms of Freundlich adsorption coefficient.

\section{ACKNOWLEDGMENTS}

The authors wish to express their thanks to Dr. S. Goto and Dr. Y. Kato for their valuable suggestions and to Dr. Y. Uesugi for his helpful advice.

\section{REFERENCES}

1) M. Takenaka \& I. Yamane: Jpn. Pestic. Inf. No. 57, 33 (1990)

2) T. Wada, S. Kuzuma, M. Takenaka \& Y. Hirota: Ann. Phytopathol. Soc. Jpn. 56, 449 (1990)

3) J. B. Petersen, K. Norris, N. C. Kaas \& K. Svanhol: Chem. Scand. 23, 1785 (1969)

4) H. Ohkawa, K. Nambu, H. Inui \& J. Miyamoto: J. Pesticide Sci. 3, 129 (1978)

5) U.S. Environmental Protection Agency: "Pesticide Assessment Guidlines," Subdivision N Chemistry, Environment Fate 64, 1982 
6) W. J. Farmer \& Y. Aochi: Soil Sci. Soc. Am. Proc. 38, 418 (1974)

7) H. M. Cheng \& J. E. Casida: J. Agric. Food Chem., 21, 1037 (1973)

8) J. Miyamoto, T. Nishida \& K. Ueda: Pestic. Biochem. Physiol. 1, 293 (1971)

9) H. Shindo \& T. Higashi: Bull. Fac. Agric. Yamaguchi Univ. 36, 13 (1988)

10) J. W. Hamaker \& J. M. Thompson: "Organic Chemicals in the Soil Environment," Marcel Dekker, Chap. 2, 49, 1972

11) U.S. Environmental Protection Agency: “Assessment of Gound Water Contamination by Pesticide," Memorandum, Jun-9, 1983

\section{要約 \\ 水田土壤中における種子消毒剤ペフラゾエート の分解および吸着}

竹中允章, 境 昭二, 西田 均 木村修一郎, 長谷 寛

水田土裹中に打けるペフラゾェート（ペンタ-4-エニ

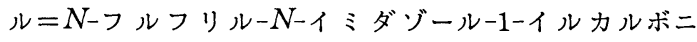
ルーDL-ホモアラニナート）の分解と土壌吸着性を, ${ }^{14} \mathrm{C}$ 標識ペフラゾエートを用いて調ベた. ペフラゾェートの 半減期は，鉱質および火山灰土壤いずれにおいても 1 週 間以内であった. ペフラゾェート添加後 6 週間目には, 添加したペフラゾエート由来の ${ }^{14} \mathrm{C}$ は約 $56 \%$ が土壌に 残留し，その他は炭酸ガスとして揮散した。主な分解生 成物として，4-ペンテニル $=N$-フルフリル-DL-ホモア ラニナート，N-フルフリル-DL-ホモアラニナート，1[(RS)-1-カルボキシラートプロピル]-3-ヒドロキシピリ ジニウム，および $N$-(フラン-2-イルカルボニル）グリ シンが同定された.これらはいずれも $10 \%$ 以下の集積 率であった.ペフラゾェートの土壤吸着性は中程度で, フロインドリッヒの吸着定数は，鉱質土壌で 16.3 , 火山 灰土壤で 21.9 であった. 